\title{
Postmortem changes in skin appendages-A histological study
}

\author{
Boban Babu ${ }^{1}$, Vina Vaswani ${ }^{2}$, Kishor Kumar.B ${ }^{3}$, Rani Nallathamby ${ }^{4 *}$ \\ ${ }^{1,4}$ Asstistant Professor, ${ }^{2}$ Head of Department, ${ }^{3}$ Associate Professor, ${ }^{1,2}$ Dept. of Forensic Medicine, ${ }^{4}$ Dept. of Anatomy, ${ }^{1,4}$ Believers Church \\ Medical College, Thiruvalla, ${ }^{2,3}$ Yenepoya Medical College, Mangalore, Karnataka, Kerala, India
}

*Corresponding Author: Rani Nallathamby

Email: raniboban@yahoo.com

\begin{abstract}
Introduction: The importance of estimating time since death was discussed through centuries, even in the most unsophisticated social setups in different parts of the world. Hair, nails, sweat and sebaceous glands are known as the appendages of the skin .They are of epithelial origin and along with the skin, forms the integumentary system. The study aims at looking into the histological changes that occurs during the decomposition process as an attempt to calculate the time since death.

Objectives: To observe various histological changes in skin and its appendages. To study time relation between these histological changes and postmortem interval.

Materials and Methods: 30 skin samples from human cadavers are collected where actual time of death is known, from Yenepoya Medical college mortuary. Skin samples $(1 \mathrm{x} 2 \mathrm{~cm})$ from the anterior chest were collected, parallel to the longitudinal midline incision. Tissues were fixed in 10\% formalin, embedded in paraffin wax, and stained with hematoxylin-eosin ( $\mathrm{H}$ and $\mathrm{E})$ and sweat glands for periodic acid-Schiff (alcian-PAS). The skin samples were observed under light microscope for the changes in the following structures: sweat glands, sebaceous glands, and hair follicles.

Result: Sebaceous glands and Hair follicle showed minimal changes that are difficult to correlate with PMI. Changes in sweat glands shared an intermediate status between the other two groups in this study which can be sought for in relation with the relation with dermis and epidermis for correlation. Sweat gland PAS staining proved to be of no definite value in this study. This study proves that histology of skin and its appendages is a powerful tool in determining time since death.
\end{abstract}

Conclusion: This study will be helpful in determination of the time since death from the changes in skin appendages.

Keywords: Postmortem Interval.

\section{Introduction}

Determination of the time since death is one of the greatest challenge in the practice of Forensic Medicine. The importance of estimating time since death was discussed through centuries, even in the most unsophisticated social setups in different parts of the world. In earlier period, the people gathered information by placing the dorsum of their hand to test the cool skin of the corpse; they evaluated changes of decomposition by observing and smelling.

The hypodermis or sub cutis is a subcutaneous layer of loose connective tissue. Hair, nails, sweat and sebaceous glands are known as the appendages of the skin. They are of epithelial origin and along with the skin, forms the integumentary system. continuous with the basal layer of epidermis.

The hair consists of a central medulla of soft keratin, a cortex and a cuticle of hard keratin. The cuticle of hair consists of thin flat scale like cells arranged on the surface like shingles.

Sebaceous glands are small saccular structures lying in dermis that empty their secretions into the upper parts of the hair follicles. The hair follicle and its associated sebaceous gland form a pilo-sebaceous unit. Sweat glands are simple tubular glands, eccrine or merocrine in variety with a highly coiled secretory tubules and long tubular excretory duct portion which are coiled into a roughly spherical ball at the border between the dermis and hypodermis.

Gross changes occurring in the skin is commonly used to estimate death interval. The gross changes that are frequently used include skin blister formation, discoloration, mummification, and/or adipocere formation. However, the timing of development of these changes are unpredictable. To counteract this problem, we can make use of histologic changes of the skin or appendages. No such study was reported from this part of the region which demands a need for such a study. Similarly, previous studies had noted the findings of the skin alone or sweat glands or hair follicles. In this study, an attempt had been made to analyze the histologic changes in the skin and appendages simultaneously and compare them with PMI.

\section{Review of literature}

Linch CA, Prahlow JA, ${ }^{1}$ conducted a study on 2001, Postmortem Microscopic Changes Observed at the Human Head Hair Proximal End, in Dallas County Institute of Forensic Sciences, in the 22 post-mortem cases. Cases were selected where an approximate time of death was known or could be determined from reviewing medical investigator reports. Hair proximal ends were photographed with a Zeiss compound microscope and observed. And he concluded that post-mortem hair proximal end morphologic changes appear to be relatively specific for the decomposition process, but the timing of their appearance is not helpful in determining post-mortem interval.

Cingolani et $\mathrm{al}^{2}$ studied the morphology of sweat glands for a period of 12 hours after death. On light microscopy, they had noted normal morphology of sweat glands for 6 hours after death, and after which vacuoles in the cytoplasm 
began to appear. On alcian-PAS stain, the secretory tubule cells progressively lost their PAS positivity within 6 hours after death. Brzezinski et $\mathrm{al}^{3}{ }^{3}$ on their study on the epidermis in refrigerated bodies, had noted the development of crescent shaped nuclei in spinous layer, surrounded by a hallow area after 1 day after death, and the number of such cells increased significantly each day during the first 8 days post-mortem. Similarly, in the basal layer, balloon shaped cells with pyknotic nuclei appeared, and with increasing PMI, focal dermo-epidermal separation was observed.

Bardale RV, Tumram NK, Dixit PG, Deshmukh AY, ${ }^{4}$ conducted a study at the Department of Forensic Medicine, Government Medical College Hospital, Nagpur.

In sweat glands they observed normal morphology up to 3 hours, Vacuoles begins to appear 4-6 hours, Ruptured cells after 15 hours. Secretory and duct cells begin to loose. In PAS staining PAS positivity maintained for 3 hours. In PAS staining basal layer appears magenta, PAS-negative secretory and duct cells, basal layer appears magenta up to 7 hours. Basal layer appears magenta after 18 hours Sebaceous Glands and Hair Follicles maintained normal morphology up to 18 hours, after which sebaceous gland showed degenerative changes and hair follicle showed disintegration of papilla.

\section{Materials and Methods}

The study was conducted at the Department of Forensic Medicine, Yenepoya Medical College, Mangalore from August 2012 to August 2014. The study consists of 30 human dead bodies comprising of 26 male and 5 female, and their age ranged from 20 to 64 years. The death was due to various causes (head injury $\mathrm{n}=12$, hanging $\mathrm{n}=6$, poisoning, $n=8$ Intracranial haemorrhage $n=12$, Natural death $n=3$, Electrocution $n=2$,). The bodies were kept at room temperature in the waiting room of the mortuary. The average ambient temperature during the period varied from $23-\mathrm{C}$ to $37-\mathrm{C}$, and the average humidity ranged from $17 \%$ to $87 \%$. At autopsy, skin samples from the anterior chest were collected, parallel to the longitudinal midline incision. The cases were divided into 0-6 hours, 6-12 hours, 12-18 hours, 18-24 hour intervals after death.

\section{Materials used}

Dissection set, metal capsules for sample collection, $10 \%$ formalin, tissue processer, microtome, L-blocks, wax, slides, covering slip, H \& E stain, PAS stains, microscope, digital camera.

\section{Methods}

2 skin samples from each dead body were collected from those bodies where actual time of death was known. Written consent was obtained from the relatives of the deceased. Certain inclusion and exclusion criteria were formulated as described below:-

\section{Inclusion criteria}

1. Sample collected from cadavers where actual time of death is known

\section{Exclusion criteria}

1. Cadavers with extensive skin diseases.

2. Cadavers with extensive tattoos over chest region.

3. Those cadavers where actual time of death is not known.

4. Death due to burns

5. Body submerged in water

Skin samples $(1 \times 2 \mathrm{~cm})$ from the anterior chest were collected, parallel to the longitudinal midline incision (figure 5). The skin samples will be carefully taken to avoid traumatic artefact. .The samples were carefully dissected out and immediately transferred to a capsule. . Tissues were fixed in $10 \%$ formalin, embedded in paraffin wax, and stained with hematoxylin-eosin ( $\mathrm{H}$ and $\mathrm{E})$ and sweat glands for periodic acid-Schiff (alcian-PAS). The skin samples were observed under light microscope for the changes in the following structures: sweat glands, sebaceous glands, and hair follicles.

\section{Observations}

Sweat glands showed minimal vacuolation (figure 1) in sample taken at $4 \mathrm{hrs}$ PMI which is showing a graduated increase over time .At 9-12 hrs, cell rupture is an additional feature. In 12-18 hours set of samples, prominent vacuoles is seen at 13 hrs sample and samples more than 15 hours, cell rupture is a feature. More than 18 hours, all samples showed prominent vacuolation (figure 2) and cell rupture (figure 3).

Sebaceous glands shoed a normal histology in $75 \%$ of samples collected at 0-6 hrs PMI and $100 \%$ of samples in 612 hours PMI.77.7\% of samples at 12-18 hours PMI and $66.6 \%$ of samples more than 18 hrs PMI showed no alteration in histology. Nuclear disintegration (figure 4,5) started at 6 hours and $22.2 \%$ of samples at 12-18 hours PMI showed the same. Vacuolation is seen in 1 sample at $6 \mathrm{hrs}$ PMI and 1 sample at $23 \mathrm{hrs}$ PMI.

$87.5 \%$ of samples of hair follicles 0-6 hr PMI set and 63.6\% of samples at 6-12 hours set along with $33.3 \%$ of slides at 12-18 hrs PMI and $66.6 \%$ of slides at more than 18 hour PMI showed no changes in histology. Vacuolation (figure 6) started at 6 hours and is seen as a feature in samples up to 19 hours without any progression. Only 1 slide t 14 hrs PMI showed prominent vacuoles.

Sweat glands on PAS staining showed cells negatively stained with a positively stained basement membrane in all the samples examined and showed no correlation with PMI (figure 7). 


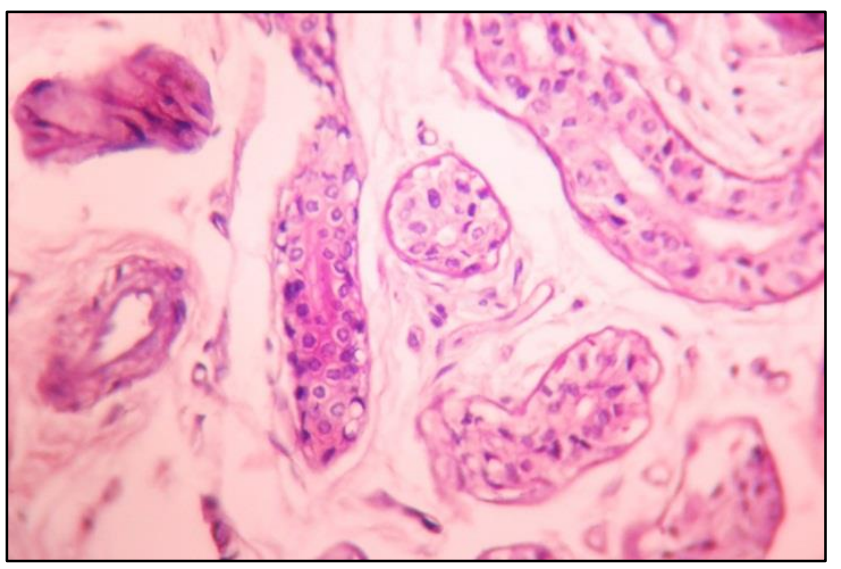

Fig. 1: Microphotograph showing sweat gland minimal vacuolation, $\mathrm{H} \& \mathrm{E}, 400 \mathrm{x}$

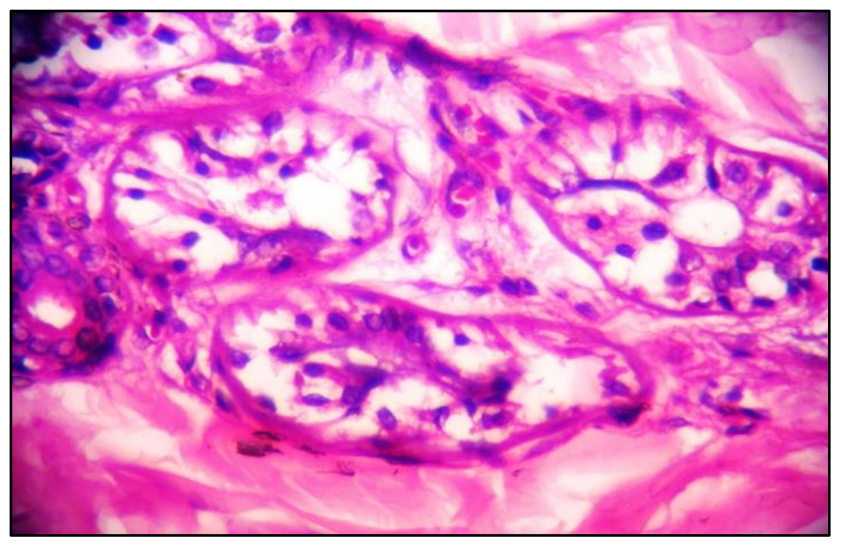

Fig. 2: Microphotograph showing sweat gland prominent vacuolation, $H \& E$, 400x

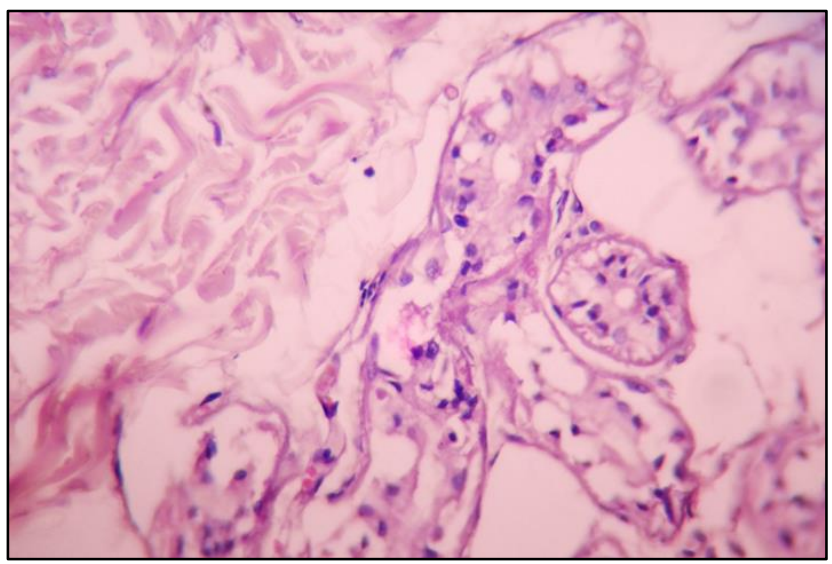

Fig. 3: Microphotograph showing sweat gland -cell rupture, $\mathrm{H} \& \mathrm{E}, 400 \mathrm{x}$

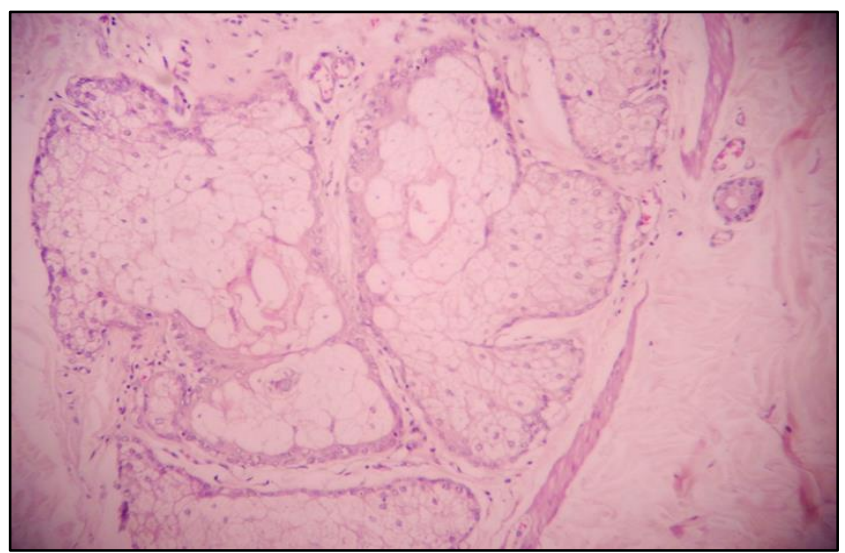

Fig. 4,5: Microphotograph showing sebaceous gland nuclear disintegration, $\mathrm{H} \& \mathrm{E}, 100 \mathrm{x}$

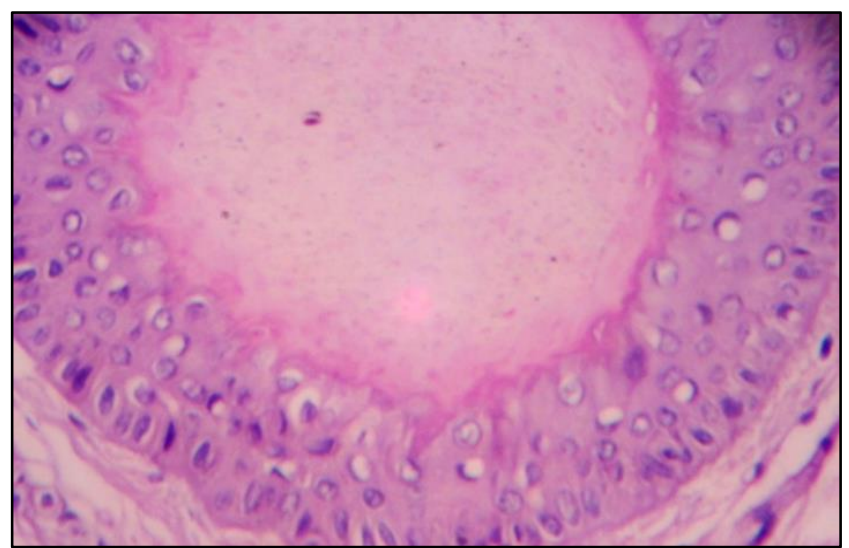

Fig.6: Microphotograph showing hair follicle vacuolations, H\&E, 100x

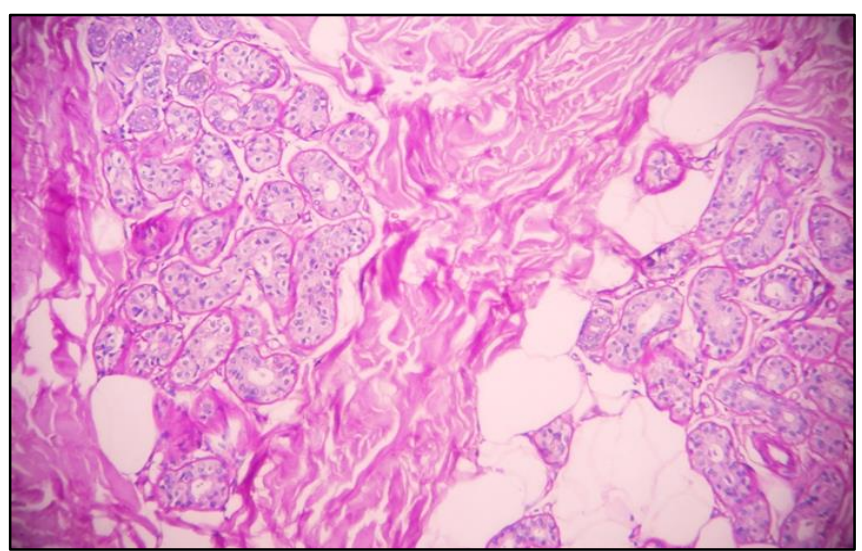

Fig.7: Microphotograph showing sweat glands showing negatively stained cells and positively stained basement membrane,PAS, 100x

\section{Results}

The results of the present study show that the skin undergoes progressive morphological changes in the post-mortem period. These changes can be observed at the cellular level by light microscopy.

Vacuolation is a prominent feature in sweat glands that starts by 4 hours getting established and more prominent as time advances. Cell rupture is getting initiated by 9 hours is a striking feature (Table 1).

Hair follicles showed normal histology up to 23 hours in 2 cases. Vacuolation is minimal getting started by 6 hours but non-progressive and showing more or less a same status over time (Table 3). 
Sebaceous glands showed no striking changes in its histology over time as most of the samples successfully maintained a normal histology in 26 cases. Vacuolation and nuclear disintegration are the main features noted but their association with PMI is inconclusive as they are seem to start appearing in samples with early as well as late PMI (Table 2).

Sweat glands on PAS staining showed cells negatively stained with a positively stained basement membrane in all the samples examined and showed no correlation with PMI and should be considered as an unreliable entity (Table 4).

Table 1: Table showing histological changes in sweat glands correlated with PMI

\begin{tabular}{|c|c|c|c|c|c|}
\hline \multirow[t]{2}{*}{ PMI [Hours] } & \multirow[t]{2}{*}{ Total no. of cases } & \multicolumn{3}{|c|}{ No. of cases showing specific features } & \multirow[t]{2}{*}{ Features in Sweat glands } \\
\hline & & No of slides & \% of Distribution & PMI of the slides(HRS) & \\
\hline \multirow[t]{7}{*}{0 -6hrs } & \multirow[t]{7}{*}{8} & 1 & $12.5 \%$ & 4 & Minimal vacuolation \\
\hline & & \multirow[t]{2}{*}{2} & \multirow[t]{2}{*}{$25 \%$} & 5 & \multirow[t]{2}{*}{ Vacuoles+ } \\
\hline & & & & 6 & \\
\hline & & \multirow[t]{3}{*}{3} & \multirow[t]{3}{*}{$37.5 \%$} & 5 & \multirow[t]{3}{*}{ Vacuoles++ } \\
\hline & & & & 6 & \\
\hline & & & & 6 & \\
\hline & & 2 & $25 \%$ & 6 & Vacuoles+++ \\
\hline \multirow[t]{9}{*}{$6-12 \mathrm{hrs}$} & \multirow[t]{9}{*}{11} & 1 & $9.09 \%$ & 9 & Vacuolest \\
\hline & & \multirow[t]{2}{*}{3} & \multirow[t]{2}{*}{$27.27 \%$} & 7 & \multirow[t]{2}{*}{ Vacuoles++ } \\
\hline & & & & $\frac{12}{12}$ & \\
\hline & & \multirow{3}{*}{4} & \multirow{3}{*}{$36.36 \%$} & 8 & \multirow{3}{*}{ Vacuoles+++ } \\
\hline & & & & 8 & \\
\hline & & & & 12 & \\
\hline & & \multirow[t]{3}{*}{4} & \multirow[t]{3}{*}{$36.36 \%$} & 9 & \multirow{3}{*}{$\begin{array}{l}\text { Vacuoles+++ with cell } \\
\text { rupture }\end{array}$} \\
\hline & & & & 10 & \\
\hline & & & & $\frac{11}{12}$ & \\
\hline \multirow[t]{8}{*}{$12-18 \mathrm{hrs}$} & \multirow{8}{*}{9} & \multirow{5}{*}{6} & \multirow{5}{*}{$66.66 \%$} & 13 & \multirow{5}{*}{ Vacuoles++ } \\
\hline & & & & 13 & \\
\hline & & & & $\frac{14}{14}$ & \\
\hline & & & & 14 & \\
\hline & & & & 18 & \\
\hline & & 1 & $11.11 \%$ & 16 & Vacuolest+t \\
\hline & & \multirow[t]{2}{*}{2} & $22.22 \%$ & 15 & Vacuoles++ +with cell \\
\hline & & & & 19 & rupture \\
\hline More than 18 & 3 & 1 & $33.33 \%$ & 23 & Vacuoles++ \\
\hline hrs & & 1 & $33.33 \%$ & 23 & Vacuoles+++ \\
\hline & & 1 & $33.33 \%$ & 19 & $\begin{array}{l}\text { Vacuoles++ +with cell } \\
\text { rupture }\end{array}$ \\
\hline
\end{tabular}

Table 2: Table showing histological changes in sebaceous glands correlated with PMI.

\begin{tabular}{|c|c|c|c|c|c|}
\hline \multirow[t]{2}{*}{ PMI[Hours] } & \multirow[t]{2}{*}{ Total no. of cases } & \multicolumn{3}{|c|}{ No. of cases showing specific features } & \multirow{2}{*}{$\begin{array}{l}\text { Features in Sebaceous } \\
\text { glands }\end{array}$} \\
\hline & & No. of slides & $\%$ of Distribution & PMI of the slides(HRS) & \\
\hline \multirow[t]{7}{*}{$0-6$} & \multirow[t]{7}{*}{8} & \multirow[t]{5}{*}{6} & \multirow[t]{5}{*}{$75 \%$} & 4 & \multirow[t]{5}{*}{ Normal histology } \\
\hline & & & & 5 & \\
\hline & & & & 5 & \\
\hline & & & & 6 & \\
\hline & & & & $\frac{6}{6}$ & \\
\hline & & 1 & $12.5 \%$ & 6 & Vacuoles + \\
\hline & & 1 & $12.5 \%$ & 6 & $\begin{array}{c}\text { Nuclear disintegration } \\
\text { started }\end{array}$ \\
\hline \multirow[t]{9}{*}{$6-12$} & \multirow[t]{9}{*}{11} & \multirow[t]{9}{*}{11} & \multirow[t]{9}{*}{$100 \%$} & 7 & \multirow[t]{9}{*}{ Normal histology } \\
\hline & & & & $\frac{7}{7}$ & \\
\hline & & & & $\frac{1}{8}$ & \\
\hline & & & & 9 & \\
\hline & & & & 9 & \\
\hline & & & & 10 & \\
\hline & & & & 11 & \\
\hline & & & & $\frac{12}{12}$ & \\
\hline & & & & 12 & \\
\hline
\end{tabular}




\begin{tabular}{|c|c|c|c|c|c|}
\hline \multirow[t]{9}{*}{$12-18$} & \multirow[t]{9}{*}{9} & \multirow[t]{7}{*}{7} & \multirow[t]{7}{*}{$77.77 \%$} & 13 & \multirow{7}{*}{ Normal histology } \\
\hline & & & & 13 & \\
\hline & & & & 14 & \\
\hline & & & & 14 & \\
\hline & & & & 14 & \\
\hline & & & & 14 & \\
\hline & & & & 15 & \\
\hline & & \multirow[t]{2}{*}{2} & \multirow[t]{2}{*}{$22.22 \%$} & 16 & \multirow{2}{*}{$\begin{array}{c}\text { Nuclear disintegration } \\
\text { started }\end{array}$} \\
\hline & & & & 18 & \\
\hline \multirow{3}{*}{$\begin{array}{c}\text { More than } 18 \\
\text { hrs }\end{array}$} & \multirow[t]{3}{*}{3} & \multirow[t]{2}{*}{2} & \multirow[t]{2}{*}{$66.66 \%$} & 19 & \multirow[t]{2}{*}{ Normal histology } \\
\hline & & & & 23 & \\
\hline & & 1 & $33.33 \%$ & 23 & Vacuoles ++ \\
\hline
\end{tabular}

Table 3: Table showing histological changes in hair follicle correlated with PMI

\begin{tabular}{|c|c|c|c|c|c|}
\hline \multirow[t]{2}{*}{ PMI[Hours] } & \multirow[t]{2}{*}{ Total no. of cases } & \multicolumn{3}{|c|}{ No. of cases showing specific features } & \multirow[t]{2}{*}{ Features in Hair follicle } \\
\hline & & No of slides & \% of distribution & PMI of the slides(HRS) & \\
\hline \multirow[t]{7}{*}{$0-6$} & \multirow[t]{7}{*}{8} & \multirow[t]{6}{*}{7} & \multirow[t]{6}{*}{$87.5 \%$} & 4 & \multirow[t]{6}{*}{ Normal histology } \\
\hline & & & & 5 & \\
\hline & & & & 5 & \\
\hline & & & & 6 & \\
\hline & & & & 6 & \\
\hline & & & & 6 & \\
\hline & & 1 & $125 \%$ & $\frac{0}{6}$ & Vacuolest \\
\hline \multirow[t]{10}{*}{$6-12$} & \multirow[t]{10}{*}{11} & \multirow[t]{6}{*}{7} & \multirow[t]{6}{*}{$63.63 \%$} & 7 & \multirow[t]{6}{*}{ Normal histology } \\
\hline & & & & 7 & \\
\hline & & & & 8 & \\
\hline & & & & 9 & \\
\hline & & & & 12 & \\
\hline & & & & $\frac{12}{12}$ & \\
\hline & & \multirow[t]{4}{*}{4} & \multirow{4}{*}{$36.36 \%$} & $\frac{12}{7}$ & \multirow{4}{*}{ Vacuoles+ } \\
\hline & & & & 9 & \\
\hline & & & & 10 & \\
\hline & & & & 11 & \\
\hline \multirow[t]{8}{*}{$12-18$} & \multirow[t]{8}{*}{9} & \multirow[t]{2}{*}{3} & \multirow[t]{2}{*}{$33.33 \%$} & 13 & \multirow[t]{2}{*}{ Normal histology } \\
\hline & & & & 13 & \\
\hline & & \multirow{5}{*}{5} & \multirow{5}{*}{$55.55 \%$} & $\frac{14}{14}$ & \multirow{5}{*}{ Vacuoles+ } \\
\hline & & & & 14 & \\
\hline & & & & 15 & \\
\hline & & & & 16 & \\
\hline & & & & 18 & \\
\hline & & 1 & $11.11 \%$ & 14 & Vacuoles+t \\
\hline \multirow{3}{*}{$\begin{array}{l}\text { More than } \\
18 \mathrm{hrs}\end{array}$} & \multirow[t]{3}{*}{3} & \multirow[t]{2}{*}{2} & \multirow[t]{2}{*}{$66.66 \%$} & 23 & \multirow[t]{2}{*}{ Normal histology } \\
\hline & & & & 23 & \\
\hline & & 1 & $33.33 \%$ & 19 & Vacuoles+ \\
\hline
\end{tabular}

Table 4: Table showing the prominent feature in each entity and its reliability on prediction of PMI

\begin{tabular}{|c|c|c|c|}
\hline Entity & Prominent feature on $\mathrm{H} \& \mathrm{E}$ staining & Correlation with PMI & Reliability \\
\hline \multirow[t]{5}{*}{ Sweat glands } & \multirow{5}{*}{$\begin{array}{l}\text { Vacuoles increasing with time and cell } \\
\text { rupture as a late feature }\end{array}$} & Minimal vacuolation $-0-4 \mathrm{hrs}$ & \multirow[t]{5}{*}{ Reliable } \\
\hline & & Vacuoles +-5-9 hrs & \\
\hline & & Vacuoles ++-5-23 hrs & \\
\hline & & Vacuoles+++-6-23 hrs & \\
\hline & & Cell rupture-9-19 hrs & \\
\hline \multirow[t]{4}{*}{ Sebaceous glands } & \multirow{4}{*}{$\begin{array}{l}\text { Minimal changes, vacuoles+ and nuclear } \\
\text { disintegration not properly correlating with } \\
\text { PMI }\end{array}$} & Normal histology-0-23 hrs & \multirow[t]{4}{*}{ Less reliable } \\
\hline & & Vacuoles+-0-6 hrs & \\
\hline & & Vacuoles++-23 hrs or more & \\
\hline & & $\begin{array}{l}\text { Intiation of Nuclear disintegration- } \\
6-18 \mathrm{hrs}\end{array}$ & \\
\hline \multirow[t]{3}{*}{ Hair follicle } & \multirow[t]{3}{*}{$\begin{array}{l}\text { Minimal changes showing non-progressive } \\
\text { minimal vacuolation }\end{array}$} & $\begin{array}{l}\text { Normal histology-0-23 hours or } \\
\text { more }\end{array}$ & \multirow[t]{3}{*}{ Less reliable } \\
\hline & & Vacuoles+-6-19 hours & \\
\hline & & Vacuoles++-0-14 hours & \\
\hline
\end{tabular}


Table 5: Findings of present study compared with past study findings

\begin{tabular}{|l|l|l|l|l|}
\hline S No. & \multicolumn{1}{|c|}{ Author } & Year of study & \multicolumn{1}{|c|}{ Population } & \multicolumn{1}{c|}{ Observation } \\
\hline 1 & Lovas JGL & 1986 & $\begin{array}{l}\text { 106 consecutive autopsy cases, } \\
\text { University of Western Ontario, } \\
\text { London. }\end{array}$ & $\begin{array}{l}\text { Apoptotic Keratinocytes in EM, Epidermal } \\
\text { necrosis }\end{array}$ \\
\hline 2 & $\begin{array}{l}\text { Cingolani } \\
\text { M et al }\end{array}$ & 1994 & $\begin{array}{l}\text { Crescent shaped nuclei in spinous layer, } \\
\text { Basal layer ballooning of cells with } \\
\text { pyknotic nuclei, } \\
\text { Dermo-epidermal separation was observed. }\end{array}$ \\
\hline 3 & $\begin{array}{l}\text { Linch CA, } \\
\text { Prahlow JA }\end{array}$ & 2001 & $\begin{array}{l}\text { 22 postmortem cases, Dallas } \\
\text { County Institute of Forensic } \\
\text { Sciences }\end{array}$ & $\begin{array}{l}\text { Postmortem hair proximal end morphologic } \\
\text { changes is specific for the decomposition } \\
\text { process, but the timing of their appearance } \\
\text { is not helpful in determining post-mortem } \\
\text { interval. }\end{array}$ \\
\hline 5 & $\begin{array}{l}\text { Kushwaha } \\
\text { M, Yadav } \\
\text { Srivastava } \\
\text { AK, } \\
\text { Agarwal A }\end{array}$ & 2010 & $\begin{array}{l}\text { 45 cases, Department of } \\
\text { Forensic Medicine G.S.V.M. } \\
\text { Medical College, Kanpur, U.P }\end{array}$ & $\begin{array}{l}\text { On histological study of kidney samples he } \\
\text { observed changes which are follows mild } \\
\text { degenerative changes. In 13-18 hrs, with } \\
\text { increasing temperature he observed } \\
\text { moderate \& severe changes seen. Only 2 } \\
\text { out of 13 cases show severe changes. In 19- } \\
\text { 24 hrs, with increasing temperature of up to, } \\
\text { severity increases. }\end{array}$ \\
\hline 7. & $\begin{array}{l}\text { Present } \\
\text { study }\end{array}$ & 2013 & $\begin{array}{l}\text { Sweat glands } \\
\text { Vacuolation sweat glands by 4 hours getting } \\
\text { Cell rupture initiated by 9 hours } \\
\text { Hair follicles } \\
\text { Normal histology in 2 cases up to 23 hours. } \\
\text { Minimal vacuolation seen in 6 hours. } \\
\text { Sebaceous glands } \\
\text { Vacuolation and nuclear disintegration } \\
\text { noted but their association with PMI is } \\
\text { inconclusive }\end{array}$ \\
\hline
\end{tabular}

\section{Discussion}

Establishing the times of an assault and death has a direct bearing on the interrogation in the court of law. If the suspect is able to prove that he was at some other region, when the particular fatal injury was inflicted to the victim, then he has an alibi to prove he is innocent and vice versa.

In cases of infanticide, the prosecution need to establish the point that the child was born alive and have to prove that death occurred after a live birth. In charred bodies recovered from fire accidents, it is critical to establish whether the death occurred before or during the fire. In a body fished out of water, the million dollar question is whether the person was alive or dead when he fell into the water. Determination of injuries made before or after death is another major example of establishment of relationship between time of the event and death.

Many physical and chemical changes start taking place in the dead body immediately after death and progress in an orderly fashion until the body disintegrates. Each change shows a rate and these rates of development of post mortem changes are strongly influenced by unpredictable endogenous and exogenous environmental factors. As a result, the estimation of the time of death becomes less precise, when the post mortem interval is longer. ${ }^{5}$

Rajesh V. Bardale ${ }^{4}$ studied the histologic changes of the skin and appendages in the early PMI, showed that skin undergoes progressive morphological changes in the postmortem period. The epidermis and the dermis appeared normal for 6 hours after death, and showed degenerative changes after this. By 6 to 9 hours after death, degeneration began in the dermis, and by the end of 18 hours, the dermis began to disintegrate. The sweat glands were seen normal for approximately 3 to 4 hours. For 18 hours after death, the sebaceous glands and hair follicles appeared normal, and after this period, degeneration began.

Considering the present study, we have sequentially studied the histologic appearance of the skin, sweat glands glands, and hair follicles in same environmental condition with average ambient temperature varied from $23-\mathrm{C}$ to $37-\mathrm{C}$ and average humidity ranged from $17 \%$ to $87 \%$.The major findings of the present study are compared with those of past literatures in (Table 5).

When the results of the present study were compared with past literatures, the histologic findings are more or less similar, but the histologic changes seems to appear earlier than the other studies, the reason for which may be the 
environmental difference as extreme environmental factors may speed up decomposition, mainly the cutaneous decomposition.

\section{Summary}

1. Sebaceous glands and Hair follicle showed minimal changes that are difficult to correlate with PMI.

2. Changes in sweat glands shared an intermediate status between the other two groups in this study which can be sought for in relation with the relation with dermis and epidermis for correlation.

3. Sweat gland PAS staining proved to be of no definite value in this study.

4. This study proves that histology of skin and its appendages is a powerful tool in determining time since death.

\section{Limitations}

This study is limited by availability of inadequate literatures, the small number of samples as Study included cases within 24 hours of death with time of death known and cases of found dead with time of death unknown were not included in the study and conduction of the study in a single environment; however, useful information can be deduced from the results. The variability of the findings reinforces the difficulty in estimating the exact time since death.

\section{Conclusion}

If multicentric studies with similar conditions are carried out, it may establish concrete periodicity of death based on the changes. This study is a potential tool in determination of time since death. There is currently very limited scientific information regarding the process of cutaneous decomposition. Studies with a larger number of cases being evaluated in different environments will throw a better light to post-mortem skin changes and their role in determination of the time since death.

\section{Source of Funding: None.}

Conflict of Interest: None.

\section{References}

1. Linch CA, Prahlow BSJ. Postmortem Microscopic Changes Observed at the Human Head Hair Proximal End. J Forensic Sci 2001;46(1):15-20.

2. Cingolani M, Osculati A, Tombolini A. Morphology of sweat glands in determining time of death. Int J Legal Med 1994; 107:132-40.

3. Brzezinski PM, Godlewski A. The assessment of post-mortem structural changes in the human epidermis. Folia Histochem Cytobiol 2002;40:211-2.

4. Bardale RV, Tumram NK, Dixit PG, Deshmukh AY. Evaluation of Histologic Changes of the Skin in Postmortem Period. Am J Forensic Med Pathol 2011.

5. Henssege C. Estimation of time since death in early postmortem period, 2nd edtion, New York: oxford university press;2002.

How to cite this article: Nallathamby $R$, Babu $B$, Vaswani V, Kishor Kumar B. Postmortem changes in skin appendages. Int $J$ Forensic Med Toxicol Sci 2019;4(4):130-6. 